\title{
Religious Nationalism in an Age of Globalization: The Case of Paraguay's "Mennonite State"1
}

DOI: http://dx.doi.org/10.1590/2236-463320161405

Benjamin W. Goossen

History Department of Harvard University, Cambridge - MA, Estados Unidos da América bengoossen@g.harvard.edu

Abstract: This article uses the example of Mennonite nation-building in Paraguay during the 1920s and 1930s to argue that state formation is not inherently modernist. Tracing nineteenth and early twentieth-century discourses of Mennonite colonies in Imperial Russia, Canada, and elsewhere as a "state within a state," the essay advocates a reevaluation of theories of modern statehood advanced by thinkers like James $\mathrm{C}$. Scott and Ernest Gellner. As conservative, pacifist Mennonites traveled from North America to the Paraguayan Chaco to escape the pressures of assimilation in democratic society, their migration paved the way for coreligionists fleeing persecution in the Soviet Union to join in the formation of a rural, autonomous "Mennonite state" that was organized internationally, characterized by deep religious observance, and conceived in opposition to high modernist projects.

Keywords: State-building, nationalism, Mennonites, modernity, diaspora, globalization

\footnotetext{
${ }^{1}$ This essay draws on research for my forthcoming book, Chosen Nation: M ennonites and Germany in a Global Era. Princeton, NJ: Princeton University Press, 2017, conducted with funding from the Fulbright Commission, the German Academic Exchange Service (DAAD), and Harvard University. I wish to thank Uwe Freisen of the Menno Colony Archive and Gunolf Niebuhr of the Fernheim Colony Archive for providing primary sources, as well as Rachel Waltner Goossen for her comments. Except where otherwise noted, all translations are my own. While all qualifications in brackets are mine, italicized words are emphasized in the original documents.
} 
During 1936 and 1937, the German geographer Herbert Wilhelmy visited Germanspeaking settlements across southern Latin America. Like other völkisch researchers from Nazi Germany, Wilhelmy was studying the influence of diasporic German settlers on their so-called "host" societies. Wilhelmy was an avid traveler and a committed nationalist-he relished the opportunity to meet and study his "co-nationals," whom he believed were preserving their racial and cultural traditions in distant settings, simultaneously transplanting German agricultural practices abroad while demonstrating their racial superiority to neighboring Latin Americans. ${ }^{2}$ Many of the groups Wilhelmy encountered seemed to conform to this description. But when the geographer arrived in the Mennonite colonies of Paraguay's northern Gran Chaco, a somewhat different interpretation emerged.

Mennonites, typically described as pacifist Christians, trace their origins to Europe's sixteenth-century Reformation. They have historically practiced adult baptism and avoided formal political participation-tenets that subjected early members to brutal persecution. While Mennonites have come from nearly every class background and social milieu, popular stereotypes have long cast them as a primarily agricultural people, bound to the land by the religious principles of simplicity and humility, as well as by the force of tradition. Many Mennonites are religiously and socially progressive, although a substantial percentage abstain from certain forms of technology such as automobiles, telephones, or the internet, further differentiating themselves from surrounding populations by wearing distinctive clothing. During the 1930s, about half a million Mennonites, of whom a majority spoke German, lived scattered across the world, primarily in Eurasia and North America. $^{3}$

That völkisch scholars frequently described the denomination as fundamentally German perhaps explains why Herbert Wilhelmy experienced such surprise upon meeting

\footnotetext{
2 SCHMIEDER, Oskar; WILHELMY, Herbert. Deutsche Ackerbausiedlungen im südamerikansichen Grasland, Pampa und Gran Chaco. Leipzig: Deutschen Museums für Länderkunde, 1938. p. 4-5. On Wilhelmy and his work, BOCK, Ulrike. Deutsche Lateinamerikaforschung im Nationalsozialismus. In: CARRERAS, Sandra, ed. Der Nationalsozialismus und Lateinamerika. Berlin: Ibero-Amerikanisches Institut Preußischer Kulturbesitz, 2005. p. 7-22.

${ }^{3}$ On Mennonite history and theology, SNYDER, Arnold. Anabaptist History and Theology. Kitchener: Pandora Press, 1995; LICHDI, Diether. Über Zürich und Witmarsum nach Addis Abeba: Die Mennoniten in Geschichte und Gegenwart. Agape Verlag, 2004.
} 
the Mennonites of rural Paraguay. ${ }^{4}$ Despite speaking fluent German and bearing nearly every other telltale characteristic of diasporic Germandom, many of these settlers seemed to see their nationality not as German, but as Mennonite. They appeared, in the geographer's estimation, to have forgotten that they were part of a larger German family. "Centuries of isolation and an astounding genealogical tradition," a deeply critical Wilhelmy assessed, "have awakened in the Mennonites the notion that they are an independent 'race' or an independent 'tribe.'"5 Moreover, the original reason that whole congregations had migrated to the "remote wilderness" of Paraguay, had not been to spread or to celebrate German culture, but exactly the opposite. They had rather come in order to keep among themselves. They had come, Wilhelmy alleged, to establish "an ideal Mennonite state." ${ }^{\prime 6}$

What was the truth to Wilhelmy's charge? Had he in fact stumbled upon a remote "Mennonite state" in rural Paraguay? The geographer's ideological commitments-his rabid nationalism, his bald racism, his anti-Semitism-render his scholarship suspect. It would without question be problematic to take his conclusions at face value. And yet, he was not simply another European returning from Latin America with fantastic tales of jungle kingdoms and rivers of gold. There were Mennonite settlers in the Paraguayan Chaco.

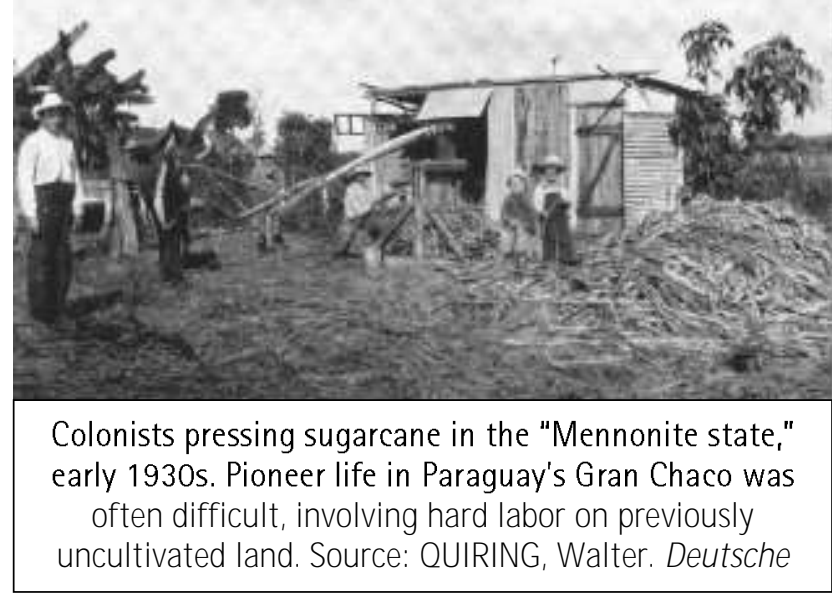

And many of them had entered the country with the intention of founding an autonomous

\footnotetext{
${ }^{4}$ On assertions of Mennonites' Germanness during the Nazi period, FOTH, Helmut. "Wie die Mennoniten in die deutsche Volksgemeinschaft hineinwuchsen": Die Mennonitischen Geschichtsblätter im Dritten Reich. Mennonitische Geschichtsblätter, n. 68, p. 59-88, 2011; GOOSSEN, Benjamin W. Mennoniten als Volksdeutsche: Die Rolle des Mennonitentums in der nationalsozialistischen Propaganda. Trans. Helmut Foth. Mennonitische Geschichtsblätter, n. 71, p. 54-70, 2014.

${ }^{5}$ SCHM IEDER and WILHELM Y. Deutsche Ackerbausiedlungen. p. 127.

${ }^{6}$ Translated in KLASSEN, Peter P. The Mennonites in Paraguay: Kingdom of God and Kingdom of this World. Hillsboro, KS: Print Source Direct, 2004. p. 92.
} 
or semi-autonomous religious settlement. In fact, by the time of Wilhelmy's visit, the words "Paraguay" and "Chaco" were well known to a large number of Mennonites living in far-flung corners of the world. The 4,000 Chaco colonists themselves represented a surprisingly broad cross-section of the global Mennonite community, hailing variously from Canada, Poland, Ukraine, and Siberia. Many had arrived with sponsorship from international Mennonite aid organizations, as well as from larger political actors ranging from the German government to the League of Nations. ${ }^{7}$

By the interwar years, references to Mennonite statism were already wellestablished. Such language had largely emerged during the late nineteenth century, around the same time that Zionism developed among European Jews. Initially, this discourse referred to Mennonite colonists living in Central Asia and the Russian Empire. Most of these individuals, numbering around 60,000, were German or Low German speaking settlers whose families had emigrated from Baltic Poland and eastern Prussia between the late eighteenth and the mid-nineteenth centuries. Under the rule of Frederick the Great and Frederick William II, the Partitions of Poland had brought Europe's largest German-speaking population of Mennonites under Prussian control. Seeking to minimize the influence of a minority that refused to participate in military service, Prussian monarchs limited their landholding and inheritance rights. Given such discrimination, it is little surprise that large numbers of Mennonites left the region for Russia, following an invitation made by Empress Catherine II in 1786, to settle newly conquered areas of the empire.

While Mennonite settlers in Central Asia and the Russian Empire often considered themselves refugees from Prussian expansionism, German nationalist observers came to term them Germanic pioneers. "We felt as if we had suddenly been transported to West Prussia," wrote the traveler August von Haxthausen upon visiting the Mennonite colonies

\footnotetext{
${ }^{7}$ For an overview of Mennonites in Paraguay, STOESZ, Edgar. Like a Mustard Seed: Mennonites in Paraguay. Scottdale, PA: Herald Press, 2008. Mennonite efforts to settle the Chaco drew in part on the transnational emergence of a discourse of self-determination described in MANELA, Erez. The Wilsonian Moment: SelfDetermination and the International Origins of Anticolonial Nationalism. Oxford: Oxford University Press, 2007. On broader patterns of twentieth-century settler colonialism, see ELKINS, Caroline; PEDERSEN Susan (eds.). Settler Colonialism in the Twentieth Century: Projects, Practices, Legacies. New York: Routledge, 2005.
} 
of South Russia in the 1840s, "so familiarly German was everything around us!"8 Drawing on a growing interest in German-speaking lands for Auslandsdeutschen, or "Germans abroad," writers like von Haxthausen emphasized the Mennonites' German language use, their farming acumen, and traits like diligence and orderliness. ${ }^{9}$ Seeking to contrast these colonists to surrounding populations, German nationalists began speaking of their settlements as constituting a "state within a state. ${ }^{10}$ When referring to population groups in Germany itself, this phrase held a derogatory connotation, especially evoking the dangers supposedly posed by J ewish or Catholic minorities. ${ }^{11}$ Yet when used in the context of Mennonites and other German speakers to the East, it rather cast the surrounding majority populations as backward, uncouth, and inferior.

Consider an 1898 article by the Hamburg-based Mennonite pastor Hinrich van der Smissen praising the "self-governance" achieved by his more easterly coreligionists. Despite early hardships of the worst sort, according to van der Smissen's telling, the Mennonite immigrants to Russia had acomplished astounding feats. The first settlers to arrive on the Dniepr River found that their trunks had been robbed in transit; devious Russian porters had replaced clothes and household appliances with stones. Yet despite further robberies, as well as the alleged ineptitude of neighboring Jewish farmers, the Mennonites built model colonies: "As diligent agriculturalists, they drew their plows through the steppes, where before only cows had grazed. Orchards sprang up on the leafles expanses, in whose protection the newly founded villages grew. If one of the first settlers could now see that region and the fields, he would be amazed at the broad expansion of the villages, the industry in the fields, and the great boom that the colonists, seen as a totality, have accomplished in 100 years." Impressed by the settlers' rich harvests and served by their factories, local Russian farmers were now said to "drive with German

\footnotetext{
${ }^{8}$ HAXTHAUSEN, August von. Studien über die inneren Zustände, das Volksleben und insbesondere die ländlichen Einrichtungen Rußlands. Hannover: Hahn'schen Hofbuchhandlung, 1847. p. 171-196.

9 See NARANCH, Bradley. Inventing the Auslandsdeutsche: Emigration, Colonial Fantasy, and German National Identity, 1848-71. In: AMES, Eric; KLOTZ, Marcia; WILDENTHAL; Lora. Germany's Colonial Pasts. Lincoln: University of Nebraska Press, 2005. p. 21-40; MANZ, Stefan. Constructing a German Diaspora: The 'Greater German Empire,' 1871-1914. New York: Routledge, 2014.

${ }^{10}$ For example, KIRCHHOF, Alfred. Die deutsche Kolonie Ak-M etschet in Khiwa. Deutsche Erde, p. 13, 1906.

${ }^{11}$ CLARK, Christopher. Religion and Confessional Conflict. In: RETELLACK, James. Imperial Germany, 18711918. Oxford: Oxford University Press, 2008. p. 96.
} 
wagons, plow with German plows, and in tilling the soil [had] adapted ever more to the German style."12

Van der Smissen's account emphsaized not only the colonists' agricultural and business accumen, however, but also their political autonomy. "Every village," according to the pastor, "was administered by a magistrate (Schulzen) elected from among the residents and formed together the official 'Regional Office," each answerable to the general superindendent (Oberschulzen), also elected from among the colonists, and his two assessors." Every Regional Office had its own bank; colonists formed their own fire insurance fund; administrators provided for orphans; and landless Mennonites were assisted with the purchasing of land in outlying "daughter settlements." ${ }^{13}$ Two decades earlier, in the 1870s, it had been the Russian government's encroachment on Mennonite autonomy that had prompted a third of the empire's subjects to depart for North America. Although an earlier Privilegium had guaranteed freedom from military conscription, an 1874 draft law revoked Mennonites' state service exemption, in turn helping to justify the mass immigration of 18,000 settlers to Canada and the United States. Immigrant leaders in both countries, to limited success, attempted to negotiate the establishment of Russianstyle privileges. ${ }^{14}$

Conservative Mennonite arrivals in Canada, particularly, sought to retain their separation from the non-Mennonite world. While Canadian officials had initialy allowed group settlement, German-language schooling, and freedom from military service, these benefits came into question several decades later during the First World War. As the British Empire declared war on Germany and its alies, patriotic Canadians criticized the nonresistance of their country's most traditionalist Mennonites, as well as their refusal to

12 SMISSEN Hinrich van der. Entwickelung und jetziger Stand der deutschen Mennonitenkolonien in Südrussland. Dr. A. Petermanns Mitteilungen aus Justus Perthes' Geographischer Anstalt, n. 44, p. 173, 1898. Historians have referred to the autonomous character of the settlements in Russia as a "Mennonite Commonwealth." See REM PEL, David G. The Mennonite Commonwealth in Russia: A Sketch of Its Founding and Endurance, 1789-1919. Mennonite Quarterly Review, n. 47, p. 259-308, 1973 and n. 48, p. 5- 54, 1974; URRY, James. The Mennonite Commonwealth in Imperial Russia Revisited. Mennonite Quarterly Review, $n$. 84, p. 229-247, 2010.

${ }^{13}$ SM ISSEN, Entwickelung und jetziger Stand... Op. Cit., p. 173.

${ }^{14}$ On Mennonites in nineteenth-century Canada and the United States, see EPP, Frank. Mennonites in Canada, 1786-1920: The History of a Separate People. Toronto: Macmillan of Canada, 1974; SCHLABACH, Theron. Peace, Faith, Nation: M ennonites and Amish in Nineteenth-Century America. Scottdale, PA: Herald Press, 1988. 
school their children in English. As such prejudices gained traction with Canadian policymakers, the British Dominion outlawed German-language education, stripped all Mennonites of their voting rights, and banned any further immigration. Conservative denominational leaders decried these measures, ascribing them to "an inextinguishable enthusiasm for the art of war" and fearing that their children would be turned into "100 percent Canadians." ${ }^{15}$ Rather than remain in democratic North America, these spokespersons began contacting governments in Latin America. By 1921, both Mexico and Paraguay had granted Mennonites a series of special privileges, offering them generous immigration and schooling rights, tax exemptions, and freedom from military service. ${ }^{16}$

Following a similar migration to northern Mexico, some 1,700 Mennonites left Canada for Paraguay, arriving by 1927. An advance party had already identified a suitable teritory in the Gran Chaco. Inhabited by indigenous peoples, it was considered free for the taking. While the first settlers suffered disease and were often disappointed by the Chaco's hot, dry climate, they eventually established a functioning colony-village names like Halbstadt, Waldheim, and Ebenfeld alleging continuity with earlier settlements in Canada, the Russian Empire, and even Prussia and Poland. Dubbed "Menno Colony," the settlement was far from the reaches of Paraguayan civil authority. Religious leaders-elders and ministers-had vitually full control over the community; M ennonite observers from North America referred to it as a "pure theocracy." In 1939, following the colony's tenth anniversary, the U.S. historian and church leader Harold Bender featured it in an important essay on "Church and State in Mennonite History." Making explicit comparisons to Mennonite self-governance in the old Russian Empire, Bender assessed that:

The autonomy of the Mennonites in the Paraguayan Chaco is greater than that of the Mennonites in Russia. As a matter of fact the Mennonites of the Chaco do constitute an absolutely independent state. There has never been any application of any of the laws of Paraguay to them in the Chaco, there has never been any police officer or government officer in the colony to exercise any authority on behalf of the national government, the courts of the land have

\footnotetext{
${ }_{15}$ Translated in LOEWEN, Royden. Village among Nations: "Canadian" Mennonites in a Transnational World, 1916-2006. Toronto: University of Toronto Press, 2013. p. 14.

${ }^{16}$ Copies of these documents are archived in Die Chaco-Expedition and Gesetz Nr. 514 und Gesetz Nr. 914. Archiv der Kolonie Menno, Loma Plata, Paraguay.
} 
never interfered with the Mennonites of the Chaco, and the army in its occupation of the Chaco has never presumed to exercise authority. ${ }^{17}$

How does this "Mennonite State" fit into established theoretical models of nationbuilding? We typically think about state formation as a modernizing phenomenon. Bureaucratization, economic planning, and the construction of heavy infrastructure characterize works on the subject. Among the most iconic studies is James C. Scott's Seeing Like a State, in which he identifies "high modernism" as quintessential state-like behavior. High modernism, for Scott, is defined by "self-confidence about scientific and technical progress, the expansion of production, the growing satisfaction of human needs, the mastery of nature (including human nature), and, above all, the rational design of social order commensurate with the scientific understanding of natural laws. ${ }^{18}$ Large industrial states like France, Brazil, or Japan may fit this definition relatively well. But what are we to make of the rural, insular "Mennonite state" described by Harold Bender or encountered by Herbert Wilhelmy? On one hand, its establishment-during the 1920s and early 1930s-corresponds precisely with the timeline offered by Scott. This was the era of centralized planning agencies like the Tennessee Valley Authority in the United States and of large-scale urban design by architects like Le Corbusier. Hitler was busy erecting one of the world's deadliest militaries. And at massive new cities like Magnitogorsk, Soviet workers tested Lenin's adage that "communism is Soviet power plus the electrification of the whole country."

Yet high modernism hardly applies to Mennonite state-building in northern Paraguay. Many settlers idealized the Chaco primarily because it was far away from large population and industrial centers. The first colonists had come to escape Canada's democratic capitalist culture, preferring to emigrate to a remote bush jungle. "For 400 years," wrote one reporter of the migration, "the Mennonites have been wandering over the face of the globe in search of a place where they can shut themselves in from the rest of the world and live in peace. They desire no intercourse with the rest of the world; they

\footnotetext{
${ }^{17}$ BENDER, Harold. Church and State in Mennonite History. M ennonite Quarterly Review, n. 13, p. 100, 1939. ${ }^{18}$ SCOTT, James C. Seeing Like a State: How Certain Schemes to Improve the Human Condition Have Failed. New Haven: Yale University Press, 1998. p. 4.
} 
merely ask to be let alone. ${ }^{19}$ During the 1920 s, Paraguayan nationalists debated whether an influx of Mennonites would threaten the country's racial composition and development prospects. While some charged that politicians should "consider superior the last Indian of the Chaco to a foolish people like... the Mennonites," policymakers ultimately admitted the settlers on the basis of their thrift and agricultural expertise. ${ }^{20}$ But if Paraguay welcomed Mennonite immigrants as modernizers in their own right, the colonists themselves favored the Chaco not for its potential as a location for high modernist projects, but because it offered a refuge from high modernism.

A second paradox. Nationalist movements-especially those organized around the formation of nation-states-have traditionally been seen as regional, secular endeavors. Regional because of the alleged ties between modernization and state formation. In Ernest Gellner's well-known formulation, national movements are brought on by industrialization. Peasants and others in primarily agrarian societies, according to Gellner, live lives too local to bring them into contact with people beyond their own immediate farms or villages. Only once they begin to circulate within a larger region as laborers do they develop a common culture that we might label "national." The resulting movements are said to be secular because they generate their own justification for being-rather than receiving a divine mandate, as in the case of Europe's ancien régime monarchies. Gellner writes that nationalized society "can and does worship itself or its own culture directly and not... through the opaque medium of religion." ${ }^{21}$

Again, it is clear that Mennonite settlers in Paraguay-to the extent that they can be considered nation builders-fit this model very poorly. The logics of Mennonite nationalism did not emerge organically among pre-national populations in the Chaco (after all, no Mennonites lived there before the 1920s) nor even among the robust congregations of early-twentieth-century Canada. While the first Mennonite immigrants to Paraguay were unlikely to speak of their efforts in explicitly nationalist terms, such language was more common among later arrivals from Eurasia. A majority of colonists to

\footnotetext{
${ }^{19}$ FRIESEN, Martin W. Canadian Mennonites Conquer A Wilderness: The Beginning and Development of the Menno Colony. Loma Plata: Historical Committee of the Menno Colony, 2009. chapter 5, section 18.

20 Translated in CHESTERTON, Bridget. The Grandchildren of Solano López: Frontier and Nation in Paraguay, 1904-1936. Albuquerque: University of New Mexico Press, 2013. p. 99.

${ }^{21}$ GELLNER, Ernest. Nations and Nationalism. Ithaca: Cornell University Press, 2006. p. 135.
} 
enter Paraguay during the interwar years, in fact, came not from Canada but from the Soviet Union. The first of these arrived in 1930. Most had previously been relatively affluent farmers whose families had decided not to leave the Russian Empire during the late nineteenth century. While their communities had prospered until the outbreak of the First World War, many had experienced discrimination in the years after the Bolshevik Revolution. Especially during Stalin's so-called "revolution from above," they faced expropriation and collectivization. Following a period of increasing assimilation within Imperial Russia-many Mennonites claimed the Tsarist state as their natural homelandtheir communities once again appeared alien and out of place.

With the intensification of Bolsheviks' campaign against alleged class enemies, thousands of M ennonites reached a breaking point. In late 1929, 13,000 German-speaking refugees, mostly Mennonites, plunged the communist empire into an international relations crisis. Abandoning their homes and descending on Moscow, these discontents demanded the right to emigrate abroad. Bolshevik authorities tried to downplay the situation, but Western reporters documented the crisis, bringing the refugees attention across the Atlantic world. German diplomats, pressured by national opinion, negotiated the transfer of several thousand to holding camps in northern Germany. At the same time, an international Mennonite welfare community mobilized to find a new homeland for the emigrants. While North American destinations like Canada and the United states remained closed to most of the refugees, many were able to travel on to Brazil-a move supported by the German government, which hoped its Mennonite wards would join an already substantial population of German speakers living there. Prominent M ennonite aid workers opposed this destination, however, since Brazil would not grant military exemption. They preferred a location where their coreligionists could live in peace, keeping among themselves. ${ }^{22}$

\footnotetext{
22 On Mennonites in the Soviet Union, see FRIESEN, John. Mennonites in Russia 1788-1988. Winnipeg, Manitoba: CM BC Publications, 1989; M ARTIN, Terry. The Russian Mennonite Encounter with the Soviet State 1917-1955. The Conrad Grebel Review, n. 20, p. 5-59, 2002. My understanding of national formation is influenced particularly by JUDSON, Pieter M. Guardians of the Nation: Activists on the Language Frontiers of Imperial Austria. Cambridge: Harvard University Press, 2006; ZAHRA, Tara. Kidnapped Souls: National Indifference and the Battle for Children in the Bohemian Lands, 1900-1948. Ithaca: Cornell University Press, 2008.
} 
This impulse benefitted from the global development of an explicitly Mennonite nationalist discourse. "Just as every star has its place in the heavens, we have our place in the constellation of nations," Mennonite leaders in Canada, the Soviet Union, and elsewhere had increasingly argued. Labeling themselves a "nation among the nations"-a phrase borrowed from Jewish nationalists-commentators invoked the dual pillars of religion and agriculture, which had allowed Mennonites to "distance themselves from other groups through race, blood, language, moral character, [and] cultural prowess." In a global climate saturated with the discourse of national self-determination, some Mennonites, like the spokespersons of other minority groups, claimed the right to aquire their own territory. Especially in the wake of terror and death in the Bolshevik empire, the notion of a separatist Mennonite enclave held appeal. Proponents insisted that although their specifically Mennonite nationality was as obvious as the dikes they had built, the swamps they had drained, and the prairies they had settled, it rarely received proper attention "because we, a closed collectivity, have never formed a formal state." ${ }^{23}$ Following the movement during the late 1920s of Canada's traditionalist Mennonites

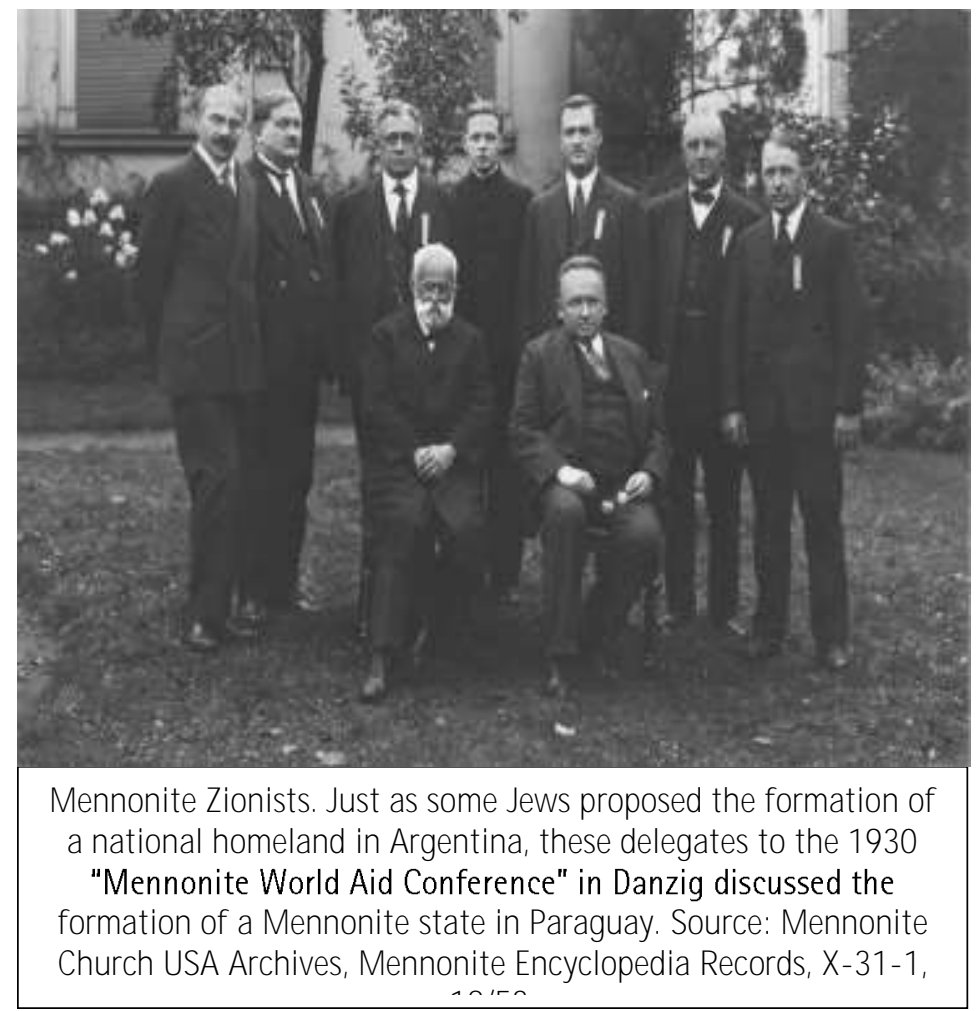
to Paraguay, the Gran Chaco seemed to provide a potential remedy.

If Mennonite nation-building in Paraguay was in no way regional, neither was it secular. In 1930, prominent church leaders from Canada, Germany, the Netherlands, and the United States gathered in Danzig to discuss the fate of the remaining refugees from

${ }^{23}$ CORNIES, H. D. Konfessionell oder national? Der Bote, p. 5-6, 21 January 1925 and p. 5-6, 28 January 1925. 
the Soviet Union. Convening a "Mennonite World Aid Conference," these delegates discussed the merits of settling the refugees in an exlusively Mennonite zone. As witnessed by some leaders' opposition to settlement in Brazil, preserving the doctrine of peaceful nonresistance played a significant role in the resettlement process. Leaders sought a solution that would allow the "little Mennonite people" to live and prosper without compromising their unique culture and its faith. Calling upon "God's gracious help and support," they aimed to provide a specifically demoninational solution to the refugee crisis. $^{24}$

Based on the recent experiences of the conservative "Menno Colony," the Gran Chaco quickly emerged as the most attractive settlement option. A young Harold Benderthe U.S. historian and church leader-spoke on behalf of the North American-based Mennonite Central Committee, explicating the factors "that convinced us of the advantages of the Paraguayan Chaco as a homeland of the Mennonites." Noting the "extremely generous concessions of the Paraguayan government," as well as the agricultural and climatic value of the vast expanse of lowland uninhabited by other European-descended groups, Bender argued that the Chaco was capable of sheltering "all the Mennonites of the world." Raising the possibility of a mass exodus of all remaining coreligionists in the Soviet Union, he envisioned "a future Mennonite state where, if possible, all Russian Mennonites could establish anew and further develop their life and culture in uninhibited freedom."25 While Stalin's anti-emigration policies prevented a majority of Mennonites from crossing Soviet borders, several thousand refugees successfully relocated to Paraguay by the mid-1930s.

The Chaco's Mennonite settlements never developed into a fully independent territory, complete with internationally recognition, passport controls, or distinct currency. The Paraguayan state retained formal sovereignty, even identifying Mennonite settlement as justification for its land claims in a bloody border war with Bolivia from 1932 to $1935 .^{26}$

24 BENDER, Harold. Die Einwanderung nach Paraguay. In: Mennonitische Welt-Hilfs-Konferenz vom 31. August bis 3. September 1930 in Danzig. Karlsruhe: Hinrich Schneider, 1930. p. 122.

25 Ibidem, p. 121-122.

${ }^{26}$ For example, "Letter from the Permanent Delegate of Paraguay to the Secretary-General," League of Nations: Official Journal, n. 13, p. 1580, 1932. On Mennonite experiences in the Chaco War, see the special 2015 issue of the Jahrbuch für Geschichte und Kultur der M ennoniten in Paraguay. 
Nor did this region ever become a haven for a majority, let alone a particularly significant percentage, of the world's Mennonites. Thousands of additional Mennonite immigrants did continue to enter Paraguay-first as refugees from devastated Europe after the Second World War, and later as conservative migrants from other parts of Latin America. Today, the country is home to approximately 36,000 Mennonites, including congregations of predominantly European descent as well as Spanish-speaking Latin Paraguayan and multilingual indigenous communities, evangelized by local Mennonite missionaries since the 1930s. Yet if Mennonites of various backgrounds are now largely considered part of the social fabric of Paraguay, the legacies of denominational nation-building persist. White, German-speaking Mennonites generally remain segregated from other Paraguayans, including non- "ethnic" Mennonites, in housing, employment, marriage, and income equality. Separate banking, insurance, and landholding systems within and beyond the Chaco continue to disproportionately benefit white Mennonite citizens, in turn lending new impetus to discussion of the colonies as a "state within a state."27

What do we learn from the strange history of Paraguay's "Mennonite state"? Previous accounts have generally smoothed over its peculiarities, assimilating the Chaco settlers into larger, well-established historical models. They thus become agents in Paraguayan state-building or diasporic German-speakers whose actions are explicable from within a framew ork of German nationalism. Such interpretations might not in a strict sense be incorrect. Yet they obscure the situation's complexity. It may be worth asking why exactly the pro-Nazi geographer Herbert Wilhelmy experienced such difficulty categorizing the "Mennonite state" within his völkisch worldview. The Chaco colonists defied Wilhelmy's expectations of minority behavior, since in his estimation, the settlers saw themselves less as subjects of a larger German race than as arbiters of an autonomous Mennonite territory. Here was a community that-drawing on discourses of nationalism and state-building arising in Europe, the Americas, and elsewhere during the nineteenth and early twentieth centuries-defied high modernism, organized internationally, and remained deeply religious.

${ }^{27}$ On contemporary Mennonites in Paraguay, Stoesz, Like a M ustard Seed... Op. Cit.

Almanack. Guarulhos, n.14, p.74-90 
I would suggest that the processes of state formation and the emergence of national movements in the nineteenth and twentieth centuries were not inherently modernist, at least in the sense of James C. Scott or Ernest Gellner. ${ }^{28}$ Neither was the "Mennonite state" a backward holdover from an earlier era, as some contemporary observers might have suggested. To the contrary, its formation depended on larger political and cultural transformations at work across the Atlantic world. In a globalized era, in which events unfolding on one continent could have radical consequences thousands of miles away, Canadian war planning could spark a religious backlash among conservative Mennonites. Similarly, Stalinist crackdowns could mobilize Mennonite nationalists on four continents. And Paraguayan development enthusiasts could enlist the aid of insular antimodernists. The formation of a religious "Mennonite state" in rural Paraguay was both enabled by and constituted a reaction against "high modernism" as well as secular, regional national movements. Perhaps it is not Paraguay's "Mennonite state," but nationbuilding as such that requires reassessment.

Data de recebimento do artigo: 28/08/2016

Data de aprovação do artigo: 25/10/2016

\section{Bibliography}

BENDER, Harold. Church and State in Mennonite History. M ennonite Quarterly Review, n. 13, p. 83-103, 1939.

---. Die Einwanderung nach Paraguay. In: Mennonitische Welt-Hilfs-Konferenz vom 31. August bis 3. September 1930 in Danzig. Karlsruhe: Hinrich Schneider, 1930. p. 117-126.

BOCK, Ulrike. Deutsche Lateinamerikaforschung im Nationalsozialismus. In: CARRERAS, Sandra (ed.). Der Nationalsozialismus und Lateinamerika. Berlin: IberoAmerikanisches Institut Preußischer Kulturbesitz, 2005.

\footnotetext{
${ }^{28} \mathrm{My}$ analysis follows COOPER, Frederick. Colonialism in Question: Theory, Knowledge, History. Berkeley: University of California Press, 2005. p. 113-152.
} 
CHESTERTON, Bridget. The Grandchildren of Solano López: Frontier and Nation in Paraguay, 1904-1936. Albuquerque: University of New Mexico Press, 2013.

CLARK, Christopher. Religion and Confessional Conflict. In: RETELLACK, James (ed.). Imperial Germany, 1871-1918. Oxford: Oxford University Press, 2008. p. 83-105.

COOPER, Frederick. Colonialism in Question: Theory, Knowledge, History. Berkeley: University of California Press, 2005.

CORNIES, H. D. Konfessionell oder national? Der Bote, p. 5-6, 21 January 1925 and p. 5-6, 28 J anuary 1925.

Die Chaco-Expedition. Archiv der Kolonie M enno, Loma Plata, Paraguay.

ELKINS, Caroline; PEDERSEN, Susan (eds.). Settler Colonialism in the Twentieth Century: Projects, Practices, Legacies. New York: Routledge, 2005.

EPP, Frank. Mennonites in Canada, 1786-1920: The History of a Separate People. Toronto: Macmillan of Canada, 1974.

FOTH, Helmut. "Wie die Mennoniten in die deutsche Volksgemeinschaft hineinwuchsen": Die Mennonitischen Geschichtsblätter im Dritten Reich. Mennonitische Geschichtsblätter n. 68, p. 59-88, 2011.

FRIESEN, John. Mennonites in Russia 1788-1988. Winnipeg, Manitoba: CM BC Publications, 1989.

FRIESEN, Martin W. Canadian Mennonites Conquer A Wilderness: The Beginning and Development of the Menno Colony. Loma Plata: Historical Committee of the M enno Colony, 2009.

GELLNER, Ernest. Nations and Nationalism. Ithaca: Cornell University Press, 2006.

Gesetz Nr. 514 und Gesetz Nr. 914. Archiv der Kolonie M enno, Loma Plata, Paraguay.

GOOSSEN, Benjamin W. Mennoniten als Volksdeutsche: Die Rolle des Mennonitentums in der nationalsozialistischen Propaganda. Trans. Helmut Foth. Mennonitische Geschichtsblätter n. 71, p. 54-70, 2014.

---. Chosen Nation: Mennonites and Germany in a Global Era. Princeton, NJ: Princeton University Press, 2017. 
HAXTHAUSEN, August von. Studien über die inneren Zustände, das Volksleben und insbesondere die ländlichen Einrichtungen Rußlands. Hannover: Hahn'schen Hofbuchhandlung, 1847.

JUDSON, Pieter M. Guardians of the Nation: Activists on the Language Frontiers of Imperial Austria. Cambridge: Harvard University Press, 2006.

KIRCHHOFF, Alfred. Die deutsche Kolonie Ak-Metschet in Khiwa. Deutsche Erde, p. 12-13, 1906.

KLASSEN, Peter P. The M ennonites in Paraguay: Kingdom of God and Kingdom of this World. Hillsboro, KS: Print Source Direct, 2004.

Letter from the Permanent Delegate of Paraguay to the Secretary-General. League of Nations: Official J ournal, n. 13, p. 1580, 1932.

LICHDI, Diether. Über Zürich und Witmarsum nach Addis Abeba: Die Mennoniten in Geschichte und Gegenwart. Agape Verlag, 2004.

LOEWEN, Royden. Village among Nations: "Canadian" Mennonites in a Transnational World, 1916-2006. Toronto: University of Toronto Press, 2013.

MANELA, Erez. The Wilsonian Moment: Self-Determination and the International Origins of Anticolonial Nationalism. Oxford: Oxford University Press, 2007.

MANZ, Stefan. Constructing a German Diaspora: The 'Greater German Empire,' 1871-1914. New York: Routledge, 2014.

MARTIN, Terry. The Russian Mennonite Encounter with the Soviet State 1917-1955. The Conrad Grebel Review, n. 20, p. 5-59, 2002.

NARANCH, Bradley. Inventing the Auslandsdeutsche: Emigration, Colonial Fantasy, and German National Identity, 1848-71. In: AM ES, Eric; KLOTZ; Marcia; WILDENTHAL, Lora (eds.). Germany's Colonial Pasts. Lincoln: University of Nebraska Press, 2005. p. 21-40.

REM PEL, David G. The Mennonite Commonwealth in Russia: A Sketch of Its Founding and Endurance, 1789-1919. Mennonite Quarterly Review, n. 47, p. 259-308, 1973 and n. 48, p. 5-54, 1947.

SCHLABACH, Theron. Peace, Faith, Nation: Mennonites and Amish in Nineteenth-Century America. Scottdale, PA: Herald Press, 1988. 
SCHMIEDER, Oskar; WILHELMY, Herbert. Deutsche Ackerbausiedlungen im südamerikansichen Grasland, Pampa und Gran Chaco. Leipzig: Deutschen Museums für Länderkunde, 1938.

SCOTT, J ames C. Seeing Like a State: How Certain Schemes to Improve the Human Condition Have Failed. New Haven: Yale University Press, 1998.

SMISSEN, Hinrich van der. Entwickelung und jetziger Stand der deutschen Mennonitenkolonien in Südrussland. Dr. A. Petermanns Mitteilungen aus Justus Perthes' Geographischer Anstalt, n. 44, p. 169-174, 1898.

SNYDER, Arnold. Anabaptist History and Theology. Kitchener: Pandora Press, 1995.

STOESZ, Edgar. Like a Mustard Seed: Mennonites in Paraguay. Scottdale, PA: Herald Press, 2008.

URRY, James. The Mennonite Commonwealth in Imperial Russia Revisited. Mennonite Quarterly Review, n. 84, p. 229-247, 2010.

ZAHRA, Tara. Kidnapped Souls: National Indifference and the Battle for Children in the Bohemian Lands, 1900-1948. Ithaca: Cornell University Press, 2008. 